Pleione 12(1): 31 - 44. 2018.

ISSN: 0973-9467

(C) East Himalayan Society for Spermatophyte Taxonomy

doi:10.26679/Pleione.12.1.2018.031-044

\title{
Distribution Pattern of Medicinal Plants Prioritized by Government of Nepal
}

\author{
Sudha Joshi (Shrestha) \\ Department of Botany, Patan Multiple Campus, Tribhuvan University, Nepal \\ E-mail:sudhashresthajoshi@gmail.com
}

[Received 19.06.2018; Revised \& accepted 26.06.2018; Published 30.06.2018]

\begin{abstract}
Government of Nepal (GoN) prioritized 33 medicinal plants (MPs) for the research and development in Nepal. Among those 33 MPs 13 MPs are prioritized for the agro-technology development. The distribution pattern in phytogeographical regions, bioclimatic zones, and elevational gradients of those prioritized MPs were reviewed from different literatures and data collected were analyzed. The analysis revealed that among the 33 prioritized MPs, all the MPs are distributed in Central Nepal. East Nepal harbours 31 and West Nepal harbours 25 prioritized GoN prioritized MPs. Maximum numbers of 19 prioritized MPs are present in lower temperate zone followed by 18 MPs in subtropical region. However, subalpine zone harbours more MPs prioritized for agro-technology development than other zones. Maximum richness for the GoN MPs is found at the elevation of $2100-2300 \mathrm{~m}$ and at $2500 \mathrm{~m}$.
\end{abstract}

Key words: Research and Development, Distribution, Prioritized, Medicinal plants, Nepal.

\section{INTRODUCTION}

From the time immemorial, indigenous plants had the history of therapeutic or prophylactic use as human and veterinary medicine, the properties of which are because of presence of bioactive chemical compounds with active physiological effects against different ailments. Nepal is endowed with the huge source of medicinal plants, which is mainly attributed because of wide range of altitudinal gradients, accompanied with climatic and edaphic factors within the small area. Use of local medicinal plants in Nepalese healthcare has the long history. Still, majority of the people residing in the rural area rely on the locally available flora or traditional medicine prepared from the plants for their health care. Medicinal plants (MPs), commonly known by the term "Jadibuti" in Nepali, the most important Non-timber Forest Products (NTFPs), is the important source of revenue collection to the government and main or additional source of income generation and livelihood for the people residing in the rural areas of the country, specially the developing like Nepal. Moreover, for the people residing in rural areas, the allopathic medicines are usually unavailable and thus have to depend on locally available MPs. About $60 \%$ population of the world and $80 \%$ population of Nepal are reported to rely on the traditional medicinal herbs to cure the health ailments (Shrestha \& Dillion 2003). Moreover, 50\% of rural households in Nepal are reported to derive their income from collection and trade of the medicinal plants (Edward 1996). Despite the high dependency of people in locally available medicinal plants either for health care or as the main or additional source of household income, the exact number of medicinal plants present in the country is still uncertain or the data differs with different literatures. Department of Plant Resources (DPR 1970, 1984) compiled 571 species, Malla and Shakya (1999) 
reported 630 species, Baral and Kurmi (2006) compiled 1792 species and Ghimire (2008) revealed 1950 species of medicinal plants in Nepal. However, at least 1463 species of herbal medicinal plants are reported to be used by people in Nepal (MoFSC 2006).

Due to effectiveness of herbal drugs and without any adverse side effects, the regional and global demands for those medicinal plants are increasing. Besides, more than $65 \%$ of the patients who used the local therapy are satisfied with such treatment (Manandhar 2002).

A bulk of literatures is available on the systematic documentation and ethnobotanical survey and traditional usage of the MPs of Nepal. Among the huge number of medicinal plants, GoN has prioritized 33 MPs for the research and economic development of the country. Commercial cultivation and trade of those prioritized and other valuable MPs are necessary for the economic growth of the country. Among the 33 prioritized MPs, GON has again selected 13 MPs for agro-technology development. However, research and development and for commercial cultivation and conservation, the distribution patterns of the species along the horizontal and vertical gradients are to be identified first. But the natural distribution patterns of those prioritized MPs are found to be variable with different literatures. As the market demand for the medicinal plants are increasing drastically in national and global level, the wild collection of those plants will not sustain for the long term survival of the species. The alternative for the wild collection is the cultivation, for which distribution patterns, habitat and suitable climatic conditions for the proper cultivation are to be evaluated and must needed. More over the relationship between species richness and elevation is important for conservation and management of species diversity (Grytnes 2003). Thus the information about the natural distribution of prioritized MPs in different phytogeographical regions and in bioclimatic zones with elevation gradients and relationship between species richness and elevation is crucial for research as well as conservation and management and agro-technology development.

The main aim of this work is to evaluate the distribution pattern of MPs prioritized by GoN in different phytogeographical regions, find elevation gradients, distribution in bioclimatic zones and species richness in elevation gradient in Nepal Himalaya to facilitate the research and development of the nation.

\section{MATERIALS AND METHODS}

\section{Data source}

Nepal Himalaya, endowed with diverse climatic, edaphic and topographic factors, harbours a large number of medicinal plants, some of which are highly valuable and proper management and propagation of those MPs have potentialities for the national development. Medicinal plants in Nepal are reported to have distributed from low land forest with $<100 \mathrm{~m}$ altitude to as high as $6100-6300 \mathrm{~m}$ altitudes (Ghimire 2008). The present study of the distribution pattern MPs in different phytogeographical regions and at different elevation gradient was focused on only $33 \mathrm{MPs}$ prioritized by the GoN. The range of distribution at phytogeographical regions viz. West, Central and East and minimum and maximum vertical elevation levels were acquired from different literatures (Joshi et al. 2017; Tripathi 2015; DPR 2011; Baniya et al. 2010; Devkota 2010; Ghimire et al. 2008; Rajbhandary \& Ranjitkar 2006; ANSAB 2003; Press et al. 2000). The valid names of the species were verified from the website (http://www.tropicos.org; http://www.theplantlist.org). The changed families of the taxa were based on the APG III (https://en.wikipedia.org/wiki/APG_III_system).

\section{Data analysis}

The data was analyzed by the Excel software. The distribution in different phytogeographical regions was analyzed by pie chart. The phytogeographical regions given by Stearn (1960); 
West Nepal with up to $83^{\circ}$ E latitude, Central Nepal between $83^{\circ} \mathrm{E}$ to $86^{\circ} 30^{\prime} \mathrm{E}$ and East Nepal from $86^{\circ} 30^{\prime} \mathrm{E}$ onwards, was followed here. The distribution of species in different bioclimatic zones was analyzed by bar diagrams. Six bioclimatic zones with 11 subzones given by Dobremez (1976) was recognized for the analysis. The species richness at particular elevation was determined by scattered plot method. The vertical elevation band of $100 \mathrm{~m}$ interval was made for overall elevation range from $100 \mathrm{~m}$ to $6000 \mathrm{~m}$. The species is considered to be present in each elevation band within its minimum level of occurrence to maximum level of occurrence. The total number of MPs present in each band was determined by interpolation (Vetaas \& Grytnes 2002; Bhattarai et al. 2004).

\section{MPs prioritized by GoN}

Department of Plant Resources, GoN has identified and prioritized 33 plants for the research and economic development of Nepal. (DPR 2006, 2016). The list of the prioritized MPs along with their family and Nepali name are given in Table 1.

Table 1. List of Medicinal Plants prioritized by Government of Nepal.

\begin{tabular}{|c|c|c|c|}
\hline $\begin{array}{l}\text { Sl. } \\
\text { No. }\end{array}$ & Scientific Name & Family & Nepali Name \\
\hline 1. & Aconitum heterophyllum Wall. ex Royle & Ranunculaceae & Atish \\
\hline 2. & $\begin{array}{l}\text { Aconitum lethale Griff. [Synonyms: Aconitum } \\
\text { spicatum (Bruhl) Stapf; Aconitum ferox var. spicatum } \\
\text { Bruhl }\end{array}$ & Ranunculaceae & Bikha \\
\hline 3. & Acorus calamus L. & Acoraceae & Bojho \\
\hline 4. & Asparagus racemosus Willd. & Asparagaceae & Satawari \\
\hline 5. & Azadirachta indica A.Juss. & Meliaceae & Neem \\
\hline 6. & Bergenia ciliata (Haw.) Sternb. & Saxifragaceae & Pakhanbhet \\
\hline 7. & Cinnamomum glaucescens (Nees) Hand.-Mazz. & Lauraceae & $\begin{array}{l}\text { Sugandha } \\
\text { kokila }\end{array}$ \\
\hline 8. & Cinnamomum tamala (Buch.-Ham.) T.Nees \& Eberm & Lauraceae & Tejpat \\
\hline 9. & Curculigo orchioides Gaertn. & Hypoxidaceae & Kalo Musali \\
\hline 10. & Dactylorhiza hatagirea (D. Don.) Soo & Orchidaceae & Panch aaule \\
\hline 11. & Dioscorea deltoidea Wall. ex Griseb. & Dioscoreaceae & Bhyakur \\
\hline 12. & Fritillaria cirrohosa D. Don. & Liliaceae & Kakoli \\
\hline 13. & Gaultheria fragrantissima Wall. & Ericaceae & Dhasingare \\
\hline 14. & Juglans regia Linn. & Juglandaceae & Ookhar \\
\hline 15. & Lichens spp & - & Jhyau \\
\hline 16. & Morchella spp. & Pezizaceae & $\begin{array}{l}\text { Khoya } \\
\text { Chyau/Guchch } \\
\text { i Chyau }\end{array}$ \\
\hline 17. & $\begin{array}{l}\text { Nardostachys jatamansi (D.Don.) DC. [Synonym: } \\
\text { Nardostachys grandiflora DC.] }\end{array}$ & Caprifoliaceae & Jatamansi \\
\hline 18. & $\begin{array}{l}\text { Neopicrorhiza scrophulariiflora (Pennell) D.Y.Hong } \\
\text { [Synonym: Picrorhiza scrophulariiflora Pennell] }\end{array}$ & Plantaginaceae & Kukti \\
\hline 19. & $\begin{array}{l}\text { Ophiocordyceps sinensis (Berk.) G.H. Sung \& } \\
\text { J.M.Sung, Hywel-Jones \& Spatafora [Synonym: } \\
\text { Cordyceps sinensis (Berk.) Sacc.] (Fungus) }\end{array}$ & $\begin{array}{l}\text { Clavicipitacea } \\
\text { e }\end{array}$ & Yarsagumba \\
\hline 20. & Paris polyphylla $\mathrm{Sm}$. & Melanthiaceae & Satuwa \\
\hline 21. & Phyllanthus emblica L. & Phyllanthaceae & Amala \\
\hline 22. & Piper longum L. & Piperaceae & Pipala \\
\hline
\end{tabular}


34 Distribution of prioritized medicinal plants in Nepal

\begin{tabular}{|c|c|c|c|}
\hline $\begin{array}{l}\text { Sl. } \\
\text { No. }\end{array}$ & Scientific Name & Family & Nepali Name \\
\hline 23. & Rauvolfia serpentina (L.) Benth. ex Kurz & Apocynaceae & Sarpagandha \\
\hline 24. & $\begin{array}{l}\text { Rheum australe D.Don [Synonym: Rheum emodii } \\
\text { Wall. ex Meisn.] }\end{array}$ & Polygonaceae & Padamchal \\
\hline 25. & Rubia manjith Roxb. ex Fleming & Rubiaceae & Majitho \\
\hline 26. & Sapindus mukorossi Gaertn. & Sapindaceae & Riththa \\
\hline 27. & $\begin{array}{l}\text { Sinopodophyllum hexandrum (Royle) T.S. Ying } \\
\text { [Synonyms: Podophyllum hexandrum Royle; } \\
\text { Podophyllum emodi Wall. ex Hoof. f. \& Thomos] }\end{array}$ & Berberidaceae & Laghupatra \\
\hline 28. & $\begin{array}{l}\text { Swertia chirayita (Roxb.ex Fleming) Karsten } \\
\text { [Synonym: Swertia chirata (Wall.) C.B.Clarke; } \\
\text { Gentiana chirayita Roxb. ex Fleming] }\end{array}$ & Gentianaceae & Chiraito \\
\hline 29. & Tagetes minuta $\mathrm{L}$. & Asteraceae & $\begin{array}{l}\text { Jangali } \\
\text { Sayapatri }\end{array}$ \\
\hline 30. & $\begin{array}{l}\text { Taxus wallichiana Zucc. [Synonym: Taxus baccata } \\
\text { subsp. wallichiana (Zucc.) Pilg.] }\end{array}$ & Taxaceae & Lautha Salla \\
\hline 31. & Tinospora sinensis (Lour.) Merr. & $\begin{array}{l}\text { Menispermace } \\
\text { ae }\end{array}$ & Gurjo \\
\hline 32. & Valeriana jatamansii Jones & Caprifoliaceae & Sugandhawal \\
\hline 33. & Zanthoxylum armatum DC. & Rutaceae & Timur \\
\hline
\end{tabular}

Among the 33 prioritized MPs, three species viz. Curculigo orchioides Gaertn., Fritillaria cirrohosa D. Don. and Paris polyphylla Sm. were prioritized in 2016 (DPR 2016) and the remaining 30 MPs had been prioritized much earlier in 2006 (DPR 2006). Moreover, within the 33 prioritized MPs 13 MPs are prioritized for agro-technology development (DPR 2006, 2016). The list of MPs prioritized for agro-technology development are: (1) Curculigo orchioides, (2) Dactylorhiza hatagirea, (3) Fritillaria cirrohosa, (4) Morchella spp. (5) Nardostachys jatamansi, (6) Neopicrorhiza scrophulariiflora, (7) Ophiocordyceps sisnensis, (8) Paris polyphylla, (9) Piper longum, (10) Rauvolfia serpentine, (11) Swertia chirayita, (12) Taxus wallichiana, and (13) Tinospora sinensis.

\section{RESULTS AND DISCUSSION}

Among the 33 prioritized MPs two species are fungi (one mushroom and one parasite), one is of lichen group, 16 species are herbs, four species are climbers, two species are shrub and eight species are trees (Table 1). The total prioritized MPs thus constitute $49 \%$ of herbs, $24 \%$ of trees, $12 \%$ of climbers, $6 \%$ of shrub and $3 \%$ each of mushroom, parasite and lichen (Figure 1).

Within the fungi, Ophicordyceps sinensis [Syn. Cordyceps sinensis] the high value medicinal plant used as tonic, is the entomopathogenic fungus belonging to the family Ascomycetes. It is endemic to the Himalayas and Tibetan Plateau and the most valued medicinal species in the world for its medicinal property (Thapa et al. 2014). The fungus parasitizes the Lepidopteran larvae especially the Himalayan bat moth Hepialus armonicanus (Gae et al. 2003; Holliday et al. 2005; Wang \& Yao 2011). Mushroom Morchella Pers., commonly known as the "morels" are also the members of sac fungi Ascomycetes and are highly cherished edible fungi (Sher \& Shan 2014) with many pharmacological values. In Nepal four species of Morchella; Morchella conica Pers. (Singh \& Nisha 1976; Adhikari 


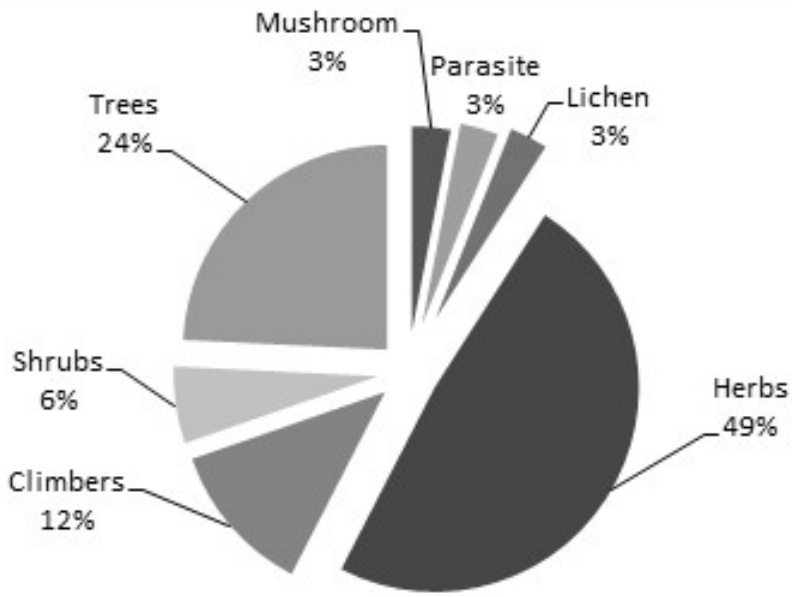

Figure 1. Different habit groups represented in the prioritized MPs.

1991), M. deliciosa Fr. (Singh \& Nisha 1976), M. esculenta Pers. (Adhikari 1991) and $M$. vulgaris (Pers.) Boud. (Adhikari \& Durrieu 1996), are reported.

Lichens, the symbiotic association of algae and fungi, of different species are also prioritized by GoN for the research and economic development of the Nation. In Nepal 465 species of lichens accounting the $2.3 \%$ of known species in the world, are reported (GoN/ MoFSC 2014). Among them, different species such as Heterodermia sp. Ramalina sp. (Devkota et al. 2017), Stereocaulon sp. (DPR 2011) are reported to have the medicinal properties. Although the distribution of lichens are influenced by the diversity of environmental variables at multiple scales (Lalley et al.2006), for the convenience, all valued lichens species are considered here as one MP for determining distribution in phytogeographical region, bioclimatic zones and species richness.

Among the prioritized spermatophytes MPs only one species Taxus wallichiana Zucc., commonly known as Himalayan yew is the gymnosperm that is well known for the medicinal properties, especially the anticancer property of the alkaloid "taxol" produced from it ( DPR 2011).

From the prioritized angiosperm MPs, six species viz. Acorus calamus Linn., Asparagus racemosus, Curculigo orchioides, Dactylorhiza hatagirea, Fritillaria cirrohosa., and Paris polyphylla are monocotyledons and other remaining MPs are dicotyledons.

\section{MPs Distribution in Phytogeographical regions}

The distribution of the prioritized MPs in different phytogeographical regions and the elevation gradients are given in Table 2.

Among the 33 MPs prioritized, 24 species (1. Aconitum lethale; 2. Acorus calamus; 3. Asparagus racemosus; 4. Bergenia ciliata; 5. Cinnamomum glaucescens; 6. Cinnamomum tamala; 7. Dactylorhiza hatagirea; 8. Dioscorea deltoidea; 9. Fritillaria cirrohosa; 10. Gaultheria fragrantissima; 11. Juglans regia; 12. Lichens; 13. Morchella spp.; 14. Nardostachys jatamansi; 15. Neopicrorhiza scrophulariiflora; 16.Ophiocordyceps sinensis; 17. Phyllanthus emblica; 18. Piper longum; 19. Rheum australe; 20. Sapindus mukorossi; 21. Sinopodophyllum hexandrum; 22. Taxus wallichiana; 23. Valeriana jatamansii and 24. Zanthoxylum armatum) accounting the $73 \%$ of the total prioritized MPs are well distributed from West Nepal to East Nepal, one species Tagetes minuta, accounting 
36 Distribution of prioritized medicinal plants in Nepal

Table 2. Life form, phytogeographic distribution and elevational gradients of prioritized MPs of Nepal.

\begin{tabular}{|c|c|c|c|c|c|c|}
\hline \multirow[t]{2}{*}{ SN } & \multirow[t]{2}{*}{ Name of Plant } & \multirow{2}{*}{$\begin{array}{l}\text { Habit } \\
\text { group }\end{array}$} & \multirow{2}{*}{$\begin{array}{c}\text { Altitudinal } \\
\text { distribution } \\
\text { (m) }\end{array}$} & \multirow[t]{2}{*}{ Region } & \multicolumn{2}{|c|}{ Reference for altitude } \\
\hline & & & & & Minimum & Maximum \\
\hline 1. & Aconitum heterophyllum & Herb & $3200-3700$ & $\mathrm{C}$ & Press et al. 2000 & Press et al.,2000 \\
\hline 2. & Aconitum lethale & Herb & $1800-4300$ & WCE & Press et al. 2000 & Ghimire et al. 2008 \\
\hline 3. & Acorus calamus & Herb & $100-2300$ & WCE & Press et al. 2000 & Press et al. 2000 \\
\hline 4. & Asparagus racemosus & Herb & $150-2740$ & WCE & DPR 2011 & Ghimire et al. 2008 \\
\hline 5. & Azadirachta indica & Tree & Upto 1500 & $\mathrm{CE}$ & - & ANSAB 2003 \\
\hline 6. & Bergenia ciliata & Herb & $1200-3600$ & WCE & ANSAB 2003 & $\begin{array}{l}\text { Rajbhandary \& } \\
\text { Ranjitkar } 2006\end{array}$ \\
\hline 7. & Cinnamomum glaucescens & Tree & $450-2500$ & WCE & ANSAB 2003 & Press et al. 2000 \\
\hline 8. & Cinnamomum tamala & Tree & $450-2500$ & WCE & Press et al. 2000 & DPR 2011 \\
\hline 9 & Curculigo orchioides & Herb & 500 & $\mathrm{CE}$ & & Press et al. 2000 \\
\hline 10. & Dactylorhiza hatagirea & Herb & $2800-4200$ & WCE & DPR 2011 & Ghimire et al. 2008 \\
\hline 11. & Dioscorea deltoidea & Climber & $450-3100$ & WCE & Joshi et al. 2017 & Joshi et al. 2017 \\
\hline 12. & Fritillaria cirrohosa & Herb & $3000-4600$ & WCE & Ghimire et al. 2008 & Ghimire et al. 2008 \\
\hline 13. & Gaultheria fragrantissima & Shrub & $1200-2700$ & WCE & ANSAB 2003 & ANSAB 2003 \\
\hline 14. & Juglans regia & Tree & $1200-3000$ & WCE & DPR 2011 & ANSAB 2003 \\
\hline 15. & Lichens spp. & Lichen & $100-7406$ & WCE & ANSAB 2003 & DPR 2011 \\
\hline 16. & Morchella spp. & $\begin{array}{l}\text { Mushro } \\
\text { om }\end{array}$ & $2000-3500$ & WCE & DPR 2011 & DPR 2011 \\
\hline 17. & Nardostachys jatamansi & Herb & $3000-5000$ & WCE & DPR 2011 & Joshi et al. 2017 \\
\hline 18. & Neopicrorhiza scrophulariiflora & Herb & $3000-4800$ & WCE & ANSAB 2003 & DPR 2011 \\
\hline 19. & Ophiocordyceps sinensis & $\begin{array}{l}\text { Entomo } \\
\text { pathoge } \\
\text { nic } \\
\text { Parasite }\end{array}$ & $3540-5050$ & WCE & Devkota 2010 & Devkota 2010 \\
\hline 20. & Paris polyphylla & Herb & $1800-3500$ & $\mathrm{CE}$ & Ghimire et al. 2008 & Ghimire et al. 2008 \\
\hline 21. & Phyllanthus emblica & Tree & $150-1600$ & WCE & Press et al. 2000 & $\begin{array}{ll}\text { Rajbhandary } & \& \\
\text { Ranjitkar 2006 }\end{array}$ \\
\hline 22. & Piper longum & Climber & $200-1000$ & WCE & DPR 2011 & ANSAB 2003 \\
\hline 23. & Rauvolfia serpentina & Shrub & $100-900$ & $\mathrm{CE}$ & Joshi et al. 2017 & Joshi et al. 2017 \\
\hline 24. & Rheum australe & Herb & $2750-4200$ & WCE & Ghimire et al. 2008 & Press et al. 2000 \\
\hline 25. & Rubia manjith & Climber & $1200-3150$ & $\mathrm{CE}$ & Press et al. 2000 & Ghimire et al. 2008 \\
\hline 26. & Sapindus mukorossi & Tree & $1000-1500$ & WCE & DPR 2011 & DPR 2011 \\
\hline 27. & Sinopodophyllum hexandrum & Herb & $2400-4500$ & WCE & DPR 2011 & DPR 2011 \\
\hline 28. & Swertia chirayita & Herb & $1200-3000$ & $\mathrm{CE}$ & DPR 2011 & DPR 2011 \\
\hline 29. & Tagetes minuta & Herb & $1250-2500$ & $\mathrm{WC}$ & DPR 2011 & DPR 2011 \\
\hline 30. & Taxus wallichiana & Tree & $1800-4400$ & WCE & DPR 2011 & Triphathi 2015 \\
\hline 31. & Tinospora sinensis & Climber & $300-1500$ & $\mathrm{CE}$ & DPR 2011 & DPR 2011 \\
\hline 32. & Valeriana jatamansii & Herb & $1500-3600$ & WCE & DPR 2011 & DPR 2011 \\
\hline 33. & Zanthoxylum armatum & Tree & $900-2500$ & WCE & DPR 2011 & DPR 2011 \\
\hline
\end{tabular}

Note $: \mathrm{W}=$ West Nepal; $\mathrm{C}=$ Central Nepal; $\mathrm{E}=$ East Nepal; Min = Minimum; Max = Maximum.

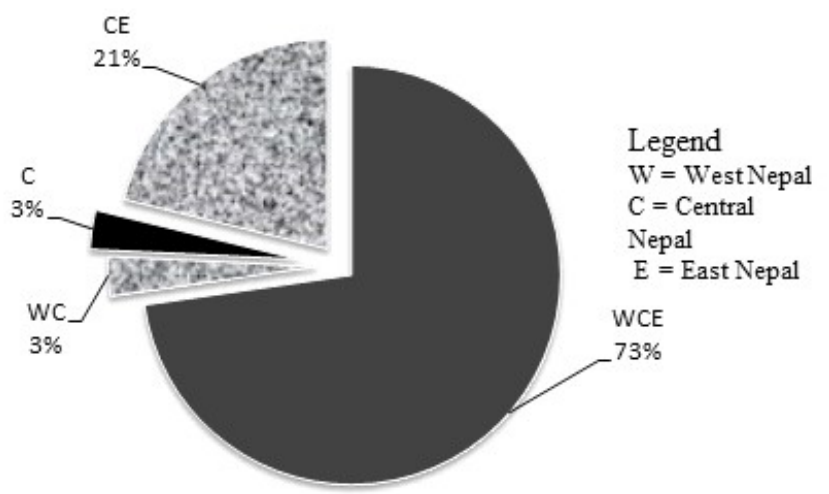

Figure 2. Distribution of prioritized MPs in Phytographical regions 
$3 \%$, is confined only in West and Central Nepal and one species Aconitum heterophyllum accounting 3\%, is confined only in Central Nepal and seven species (1. Azadirachta indica; 2. Curculigo orchioides; 3. Paris polyphylla; 4. Rauvolfia serpentina; 5. Rubia manjith; 6. Swertia chirayita and 7. Tinospora sinensis) accounting the $21 \%$ of the total prioritized MPs are distributed in Central and East Nepal (Figure 2).

All the 13 MPs prioritized for agro-technology development are well distributed in Central and East Nepal. Among the 13 MPs, 5 MPs viz. Curculigo orchioides, Paris polyphylla, Rauvolfia serpentina, Swertia chirayita and Tinospora sinensis are absent from West Nepal.

The analysis thus revealed that Central Nepal harbours all 33 GoN prioritized MPs followed by East Nepal with 31 species and West Nepal with 25 species (Table 1). In Nepal, the intensity of rainfall decreases gradually from east to west and increases from plain to certain elevation between 800 to $2000 \mathrm{~m}$ to north and then again decreases (Acharya et al. 2009). More prioritized MPs being confined to Central and East Nepal could possibly due to this pattern of precipitation. Dryness of west Nepal could possibly related with less number of prioritized MPs in this region.

\section{MPs distribution in Bioclimatic Zones and elevation gradients}

Among the prioritized 33 MPs, maximum number of 19 prioritized MPs are present in lower temperate region followed by 18 MPs in upper subtropical region, 17 in lower subtropical region, 16 each in upper temperate and lower subalpine region, 13 in upper subalpine, 12 in upper and lower tropical region, 10 in lower alpine region, 5 in upper alpine region and 2 species in above the alpine region (Figure 3). The lists of prioritized MPs distributed in different bioclimatic zones are as follow:

\section{Tropical zone}

Among the 33 MPs prioritized, 12 species present in lower tropical zone are: 1. Acorus calamus; 2. Asparagus racemosus; 3. Azadirachta indica; 4. Cinnamomum glaucescens; 5. Cinnamomum tamala; 6. Curculigo orchioides; 7. Dioscorea deltoidea; 8. Lichens; 9. Phyllanthus emblica; 10. Piper longum; 11. Rauvolfia serpentina; and 12. Tinospora sinensis.

Among the 33 MPs prioritized, 13 species present in upper tropical zone are: 1. Acorus calamus; 2. Asparagus racemosus; 3. Azadirachta indica; 4. Cinnamomum glaucescens; 5. Cinnamomum tamala; 6. Dioscorea deltoidea; 7. Lichens; 8. Phyllanthus emblica; 9. Piper longum; 10. Rauvolfia serpentina; 11. Sapindus mukorossi; 12. Tinospora sinensis and 13. Zanthoxylum armatum.

Altogether 14 prioritized MPs are found in tropical zone. Within those MPs Curculigo orchioides is distributed only in lower tropical zone and Sapindus mukorossi is present only in upper tropical zone.

Among the 14 prioritized MPs present in this zone, 4 MPs (Curculigo orchioides, Piper longum, Rauvolfia serpentina; and Tinospora sinensis) are prioritized for agrotechnology development.

\section{Subtropical zone}

Among the 33 MPs prioritized, 17 species present in lower subtropical zone are: 1. Acorus calamus; 2. Asparagus racemosus; 3. Azadirachta indica; 4. Bergenia ciliata; 5. Cinnamomum glaucescens; 6. Cinnamomum tamala; 7. Dioscorea deltoidea; 8. 
Gaultheria fragrantissima; 9. Juglans regia; 10. Lichens; 11. Phyllanthus emblica; 12. Rubia manjith; 13. Sapindus mukorossi; 14. Swertia chirayita; 15. Tagetes minuta, 16. Tinospora sinensis and 17. Zanthoxylum armatum.

Among the 33 MPs prioritized, 18 species present in upper sub-tropical zone are: lower tropical zone are: 1. Aconitum lethale; 2. Acorus calamus; 3. Asparagus racemosus; 4. Bergenia ciliata; 5. Cinnamomum glaucescens; 6. Cinnamomum tamala; 7. Dioscorea deltoidea; 8. Gaultheria fragrantissima; 9. Juglans regia; 10. Lichens; 11. Paris polyphylla; 12. Phyllanthus emblica; 13. Rubia manjith; 14. Swertia chirayita; 15. Tagetes minuta Linn.; 16. Taxus wallichiana; 17. Valeriana jatamansii and 18. Zanthoxylum armatum.

Altogether 21 species of prioritized MPs are found in subtropical zone. Within those MPs Azadirachta indica, Sapindus mukorossi and Tinospora sinensis are distributed up to lower subtropical region and MPs Aconitum lethale, Taxus wallichiana and Valeriana jatamansii are distributed from only upper subtropical zone.

Among the 21 prioritized MPs present in this zone, 4 MPs [Paris polyphylla, Swertia chirayita, Taxus wallichiana and Tinospora sinensis] are prioritized for agro-technology development.

\section{Temperate zone}

Among the 33 MPs prioritized, 19 species present in lower temperate zone are: 1. Aconitum lethale; 2. Acorus calamus; 3. Asparagus racemosus; 4. Bergenia ciliata; 5. Cinnamomum glaucescens; 6. Cinnamomum tamala; 7. Dioscorea deltoidea; 8. Gaultheria fragrantissima; 9. Juglans regia; 10. Lichens; 11. Morchella spp.; 12. Paris polyphylla; 13. Rubia manjith; 14.Sinopodophyllum hexandrum; 15. Swertia chirayita; 16. Tagetes minuta; 17. Taxus wallichiana; 18. Valeriana jatamansii and 19. Zanthoxylum armatum.

Among the 33 MPs prioritized, 16 species present in upper temperate zone are: 1. Aconitum lethale; 2. Asparagus racemosus; 3. Bergenia ciliata; 4. Dactylorhiza hatagirea; 5. Dioscorea deltoidea; 6. Gaultheria fragrantissima; 7. Juglans regia; 8. Lichens; 9. Morchella spp.; 10. Paris polyphylla; 11. Rheum australe; 12. Rubia manjith; 13. Sinopodophyllum hexandrum; 14. Swertia chirayita; 15 . Taxus wallichiana and 16. Valeriana jatamansii.

Altogether 21 species of prioritized MPs are thus present in temperate zone. Among them MPs Acorus calamus, Cinnamomum glaucescens, Cinnamomum tamala, Tagetes minuta and Zanthoxylum armatum are distributed up to the lower temperate region only and MPs Dactylorhiza hatagirea and Rheum australe are distributed only from upper temperate zone.

Among the 21 prioritized MPs present in this zone, 5 MPs [Dactylorhiza hatagirea, Morchella spp., Paris polyphylla, Swertia chirayita and Taxus wallichiana] are prioritized for agro-technology development.

\section{Subalpine zone}

Among the 33 MPs prioritized, 16 species present in lower subalpine zone are: 1. Aconitum heterophyllum; 2. Aconitum lethale; 3. Bergenia ciliata; 4.. Dactylorhiza hatagirea; 5. Dioscorea deltoidea; 6. Fritillaria cirrohosa; 7. Lichens; 8. Morchella spp.; 9. Nardostachys jatamansi; 10. Neopicrorhiza scrophularifflora; 11. Paris polyphylla; 12. Rheum australe; 13. Rubia manjith; 14. Sinopodophyllum hexandrum; 15. Taxus wallichiana and 16. Valeriana jatamansii. 
Among the 33 MPs prioritized, 13 species present in upper subalpine zone are: 1 . Aconitum heterophyllum; 2. Aconitum lethale; 3. Bergenia ciliata; 4. Dactylorhiza hatagirea; 5. Fritillaria cirrohosa; 6. Lichens; 7. Nardostachys jatamansi; 8. Neopicrorhiza scrophulariiflora; 9. Ophiocordyceps sinensis; 10. Rheum australe; 11. Sinopodophyllum hexandrum; 12 Taxus wallichiana and 13. Valeriana jatamansii.

Altogether 17 prioritized MPs are present in subalpine zone. Among those prioritized MPs Dioscorea deltoidea, Morchella spp, Paris polyphylla and Rubia manjith have the upper limit up to the lower subalpine region only and one Medicinal Plant Ophiocordyceps sinensis starts its distribution from the upper subalpine zone only.

Among the 17 prioritized MPs present in this zone, 8 MPs [Dactylorhiza hatagirea, Fritillaria cirrohosa, Morchella spp., Nardostachys jatamansi, Neopicrorhiza scrophulariiflora, Ophiocordyceps sinensis, Paris polyphylla and Taxus wallichiana] are prioritized for agro-technology development.

\section{Alpine zone}

Among the 33 MPs prioritized, 10 species present in lower alpine zone are: 1. Aconitum lethale Griff.; 2. Dactylorhiza hatagirea; 3. Fritillaria cirrohosa; . 4 . Lichens; 5. Nardostachys jatamansi; 6. Neopicrorhiza scrophulariiflora; 7. Ophiocordyceps sinensis; 8. Rheum australe; 9. Sinopodophyllum hexandrum; and 10. Taxus wallichiana.

Among the 33 MPs prioritized, 5 species present in upper alpine zone are: 1. Fritillaria cirrohosa; 2. Lichens spp.; 3. Nardostachys jatamansi; 4. Neopicrorhiza scrophulariiflor; and 5. Ophiocordyceps sinensis.

Altogether 10 prioritized MPs are present in alpine zone. Among those them 5 MPs Aconitum lethale, Dactylorhiza hatagirea, .Rheum australe, Sinopodophyllum hexandrum and Taxus wallichiana are found up to the lower alpine zone and only 5 MPs Fritillaria cirrohosa, Lichens, Nardostachys jatamansi, Neopicrorhiza scrophulariiflora and Ophiocordyceps sinensis are found up to the upper alpine zone.

Among the 10 prioritized MPs present in this zone, 6 MPs [Dactylorhiza hatagirea, Fritillaria cirrohosa, Nardostachys jatamansi, Neopicrorhiza scrophulariiflora, Ophiocordyceps sinensis and Taxus wallichiana] are prioritized for agro-technology development.

\section{Above Alpine zone}

Only two prioritized MPs, lichen species and Ophiocordyceps sinensis are reported from above alpine zone. Lecanora polytropa lichen is reported from about $7406 \mathrm{~m}$ (DPR 2011). Ophiocordyceps sinensis (Yarsagumba) is reported up to $5050 \mathrm{~m}$ which is almost up to alpine zone only.

The analysis thus revealed that the MPs prioritized gradually increased in number from lower tropical zone with 12 species and peaked at the lower temperate zone with the maximum of 19 MPs and again decreased gradually with the higher elevation showing the humped relationship with the bioclimatic zones (Figure 3). However the subalpine zone harbours more MPs prioritized for agro-technology development than other bioclimatic zones.

The species like Aconitum heterophyllum and Curculigo orchioides have the narrow elevational gradient of about $500 \mathrm{~m}$ only while the species like Dioscorea deltoidea has the wide elevational gradient of about $2650 \mathrm{~m}$ (Table 1). More over the tropical species such as Curculigo orchioides, Piper longum, Rauvolfia serpentina are limited only to the tropical 


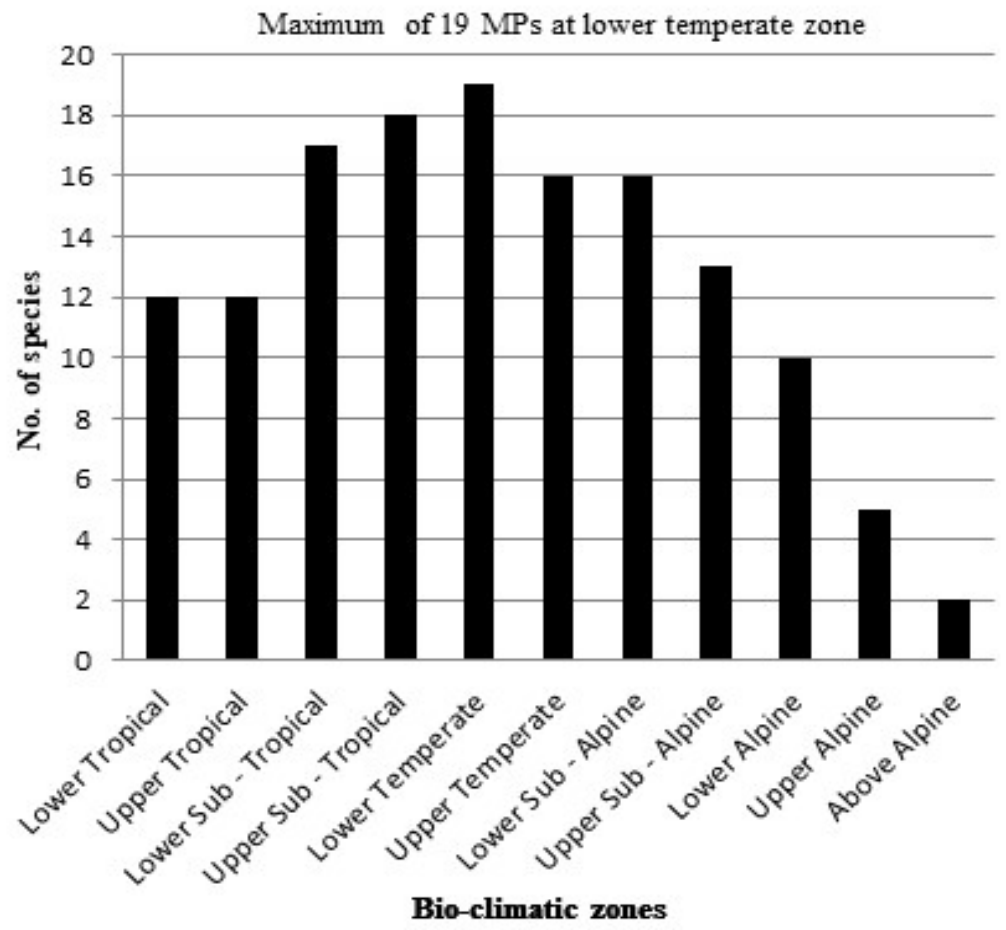

Figure 3. Prioritized MPs in Bio-climatic Zones

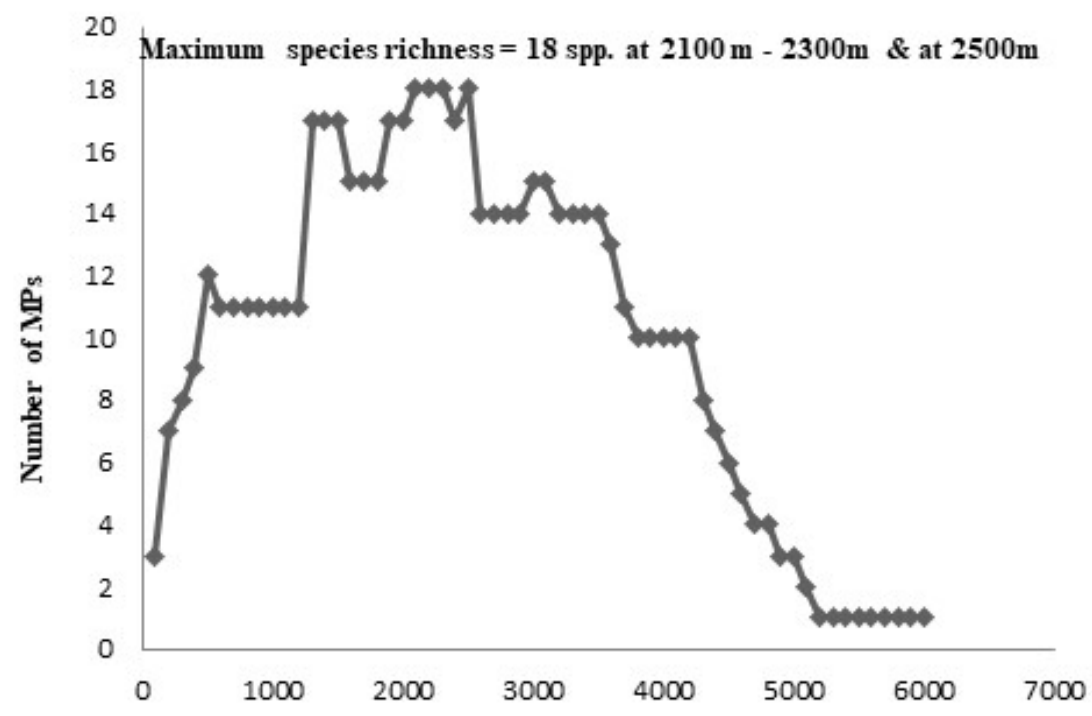

Figure 4. Relationship between elevation and prioritized MPs.

zone (Table 2). Though the lichens have the maximum elevation gradient up to $7406 \mathrm{~m}$ for the species Lecanora polytropa (DPR 2011) but the species like Parmelia nepalensis and Ramalina subcomplanata are reported to have the elevation range from $100 \mathrm{~m}$ to $3000 \mathrm{~m}$ (ANSAB 2003). In general, the temperate zone represents the maximum lichen richness (Baniya et al. 2010). 


\section{Species richness}

The maximum number of 18 prioritized MPs are distributed from $2001 \mathrm{~m}$ to $2300 \mathrm{~m}$ (at 2100 $\mathrm{m}-2300 \mathrm{~m}$ ) and from $2401 \mathrm{~m}$ to $2500 \mathrm{~m}$ (at $2500 \mathrm{~m}$ ) at lower temperate zone followed by the 17 prioritized MPs at subtropical zone from $1201 \mathrm{~m}$ to $1500 \mathrm{~m}$ (at $1300 \mathrm{~m}-1500 \mathrm{~m}$ ) and from $1801 \mathrm{~m}$ to $2000 \mathrm{~m}$ (at $1900 \mathrm{~m}$ to $2000 \mathrm{~m}$ ) and at 2400 (Figure 4). However, the species richness for the 60 species of MPs of various risk categories was observed at lower subtropical zone at elevation of $1100 \mathrm{~m}$ (Acharya et al. 2009). Moreover the species richness was observed at $1000 \mathrm{~m}$ for the medicinal vascular plants (Rokaya et al. 2012). The present result on the species richness on the GoN prioritized MPs is in contrary to the previous results for MPs. Similarly, the foliose lichens are reported to have their maximum richness between $2400-2500 \mathrm{~m}$ (Baniya et al. 2010). The present analysis thus revealed that the high value MPs that have the potentiality for the economic development of nation are peaked at the lower temperate zone. More prioritized MPs at lower temperate and upper subtropical zones could possibly due to optimum environmental conditions, edaphic factors and less anthropogenic disturbance.

\section{Conservation Status}

Some of the prioritized MPs are also under the risk category of IUCN. Among them Aconitum heterophyllum and Taxus wallichiana are endangered and Nardostachys jatamansi is critically endangered (http://www.iucnredlist.org/search).

Among the prioritized MPs Dactylorhiza hatagirea; Dioscorea deltoidea, Nardostachys jatamansi, Sinopodophyllum hexandrum, Rauvolfia serpentina and Taxus wallichiana are under the CITES Appendix II (Joshi et al. 2017).

GoN under the Forest Act 1993 has protected some of the MPs which also includes some MPs prioritized by GoN (GoN 2001, 2003). Those include MPs Dactylorhiza hatagirea, Neopicrorhiza scrophulariiflora, Juglans regia (Bark) under category I (Plants banned for collection, use, sale, distribution transportation and export); Cinnamomum glaucescens, Nardostachys jatamansi, Rauvolfia serpentina, Taxus wallichiana, Valeriana jatamansii under category II (Plants banned for export outside country in unprocessed form) and Juglans regia under Category III (Plants banned for transportation, export and felling for commercial purpose).

\section{CONCLUSION}

The present study revealed that all GoN prioritized MPs are distributed in Central Nepal followed by the East Nepal with 31 prioritized MPs and 25 MPs in West Nepal. Among the 33 prioritized MPs 19 MPs are present in lower temperate zone followed by 18 MPs at upper subtropical zone indicating that the upper subtropical to lower temperate zones are the most suitable habitats for the prioritized MPs. The maximum prioritized MPs richness is found at the elevation of $2100-2300 \mathrm{~m}$ and at $2500 \mathrm{~m}$ which is in contrary to $1100 \mathrm{~m}$ and $1000 \mathrm{~m}$ revealed by Acharya et al. (2009) and Rokaya et al. (2012) respectively analyzed for the MPs of Nepal. It probably indicates the MPs with potentialities for development of the nation are more at the higher elevation than on the lower elevations. Knowledge about the distribution patterns on horizontal and vertical gradients are crucial for the conservation and management as well as the cultivation of the MPs that could contribute to the economic development of the nation. It is thus envisaged the present study will help in conservation practices as well as in research for developing the Good Agriculture and Collection Practices (GACP) of GoN prioritized MPs. 


\section{LITERATURE CITED}

Acharya, K.P.; Chaudhary, R.P. \& Vetaas, O.R. 2009. Medicinal plants of Nepal: Distribution pattern along an elevational gradient and effectiveness of existing protected areas for their conservation. Banako Jankari, 19 (1): 16 - 22.

Adhikari, M.K. \& Durrieu, G. 1996. Ethnomycologie nepalaise. Bull. Soc. Myc. France. 112: $31-41$.

Adhikari, M.K. 1991. Notes on some higher fungi from Nepal. J. Nat. Hist. Mus.. 12(1-4): 9-18.

ANSAB. 2003. Commercially Important Non Timber Forest Products (NTFPs) of Nepal. Publ. Asia Network for Sustainable Agriculture and Bioresources. Kathmanu, Nepal.

Baniya, C.B.; Solhoy, T.; Gauslaa,,Y. \& Palmer, M.W. 2010. The elevation gradient of lichen species richness in Nepal. The Lichenologist, 42 (1): 83-96. doi:10.1017/ S0024282909008627

Baral, S.R. \& Kurmi, P.P.2006. A Compendium of Medicinal Plants in Nepal. Mrs. Rachana Sharma, Kathmandu, Nepal.

Bhattarai, K.R.; Vetaas, O.R. \& Grytnes, J.A. 2004. Fern species richness along a central Himalayan elevation gradient, Nepal. J. Biogeogr. 31: $389-400$.

Devkota, S.; Chaudhary, R.P.; Werth, S. \& Scheidegger, C. 2017.Indigenous knowledge and use of lichens by the lichenophilic communities of the Nepal Himalaya. J. Ethnobio. Ethnomed. 13: 15. doi: 10.1186/s13002-017-0142-2.

Devkota, S. 2010. Ophiocordyceps sinensis (Yarsagumba) from Nepal Himalaya: Status, Threats and Management Strategies. In: Zhang Ping Hao-wei (ed.), Cordyceps Resources and Environment. Grassland Supervision Center, Ministry of Agriculture, Peoples's Republic of China. Pp. 91 - 108. doi:10.1111/j.1365-2699.2011.02596.

Dobremez, J.F. 1976. Le Nepal Ecologie et Biogeographie (Nepal Ecology and Biography). Paris : Centre Nationale de la Recherche Centifique.

DPR. 1970. Medicinal Plants of Nepal. Bulletin of the Department of Medicinal Plants No. 3. Department of Forestry and Plant Research, Ministry of Forest and Soil Conservation, Government of Nepal, Kathmandu, Nepal.

DPR. 1984. Medicinal Plants of Nepal. Bulletin of the Department of Medicinal Plants No. 10. Department of Forestry and Plant Research, Ministry of Forest and Soil Conservation, Government of Nepal, Kathmandu, Nepal.

DPR, 2006. Plants of Nepal: Fact Sheet. Department of Plant Resources, Ministry of Forest and Soil Conservation, Thapathali, Kathmandu, Nepal.

DPR, 2011. Prioritized Medicinal Plants for Economic Development in Nepal. Department of Plant Resources, Ministry of Forest and Soil Conservation, Government of Nepal, Kathmandu. (In Nepali, $4^{\text {th }}$ edition).

DPR, 2016. News letter (Banaspati Shrota). Department of Plant Resources, Ministry of Forest and Soil Conservation, Thapathali, Kathmandu, Nepal. 19 (4).

Edward, D.M. 1996. Non Timber Forest Products from Nepal: aspects of Trade in Medicinal and Aromatic Plants. Forest Research and Survey Centre Monograph 1/ 96. Ministry of Forests and soil Conservation, Kathmandu, Nepal.

Gao, H.C.; Gao, J.Q.; Xi, Q.Y. \& Li, X.H. 2003. Research and development for Cordyceps sinensis. J. Microb. 23: $50-55$. 
Ghimire, S.K. 2008. Medicinal Plants in the Nepal Himalaya: Current issues, Sustainable harvesting, Knowledge gaps and Research priorities. In: Jha, P.K., Karmacharya, S.B., Chettri, M.K. Thapa, C.B. and Shrestha, B.B. (eds.), Medicinal Plants in Nepal: An Anthology of Contemporary Research. Publ. Ecological Society (ECOS), Kathmandu, Nepal.

Ghimire, S.K.; Sapkota, I.B.; Oli, B.R. \& Parajuli, R.R. 2008. Non-Timber Forest Products of Nepal Himalaya: Database on Some Important Species Found in the Mountain Protected Areas and Surrounding Regions. WWF Nepal, Kathmandu, Nepal.

GoN/MoFSC 2014. Nepal National Biodiversity Strategy and Action Plan: 2014-2020. Ministry of Forest and Soil Conservation, Government of Nepal, Kathmandu, Nepal.

GoN 2001. Nepal Rajpatra (Part 3), Section 51. Date: B.S. 2058-9-16. Government of Nepal, Kathmandu, Nepal.

GoN 2003. Nepal Rajpatra (Part 3), Section 53. Date: B.S. 2060-8-1. Government of Nepal, Kathmandu, Nepal.

Grytnes, J.A. 2003. Species-richness patterns of vascular plants along seven altitudinal transects in Norway. Ecography, 26: 291-300.

Holliday, J.; Cleaver, M. \& Wasser, S.P. 2005. Cordyceps. In: Coates, P.M., Blackman, M.R., Cragg, G., Levine, M., Moss. J. \& White, J. (eds.). Encyclopedia of Dietary Supplements. Marcel Dekker, New York. Pp. 1-13.

Joshi, N.; Sharma (Dhakal), K. \& Saud, D.S. 2017. Checklist of CITES listed Flora of Nepal. Department of Plant Resources, Ministry of Forests and Soil Conservation, GoN. Kathmandu, Nepal.

Lalley, J.S.; Viles, H.A.; Copeman, N. \& Cowley, C. 2006. The influence of multi-scale environmental variables on the distribution of terricolous lichens in a fog forest. $J$. Veg. Sci. 17: $831-838$.

Malla, S.B. \& Shakya, P.R. 1999. Medicinal Plants. In: Majupuria, T.C. (ed.),Nepal Nature's Paradise.. Publ. M. Devi, Gwalior, India: Pp. 267 - 297.

Manandhar, N.P. 2002. Plants and People of Nepal. Timber press, Portland, Oregon97204, USA: pp. 52.

MoFSC, 2006. Nepal: Third National Report to the Convention on Biological Diversity. Ministry of Forest and Soil Conservation. Government of Nepal, Kathmandu, Nepal.

Press, J.R.; Shrestha, K.K. \& Sutton, D.A. 2000. Annotated Checklist of the Flowering Plants of Nepal. Natural History Museum, London.

Rajbhandary, S. \& Ranjitkar, S. 2006. Herbal Drugs and Pharmacogonosy: Monographs on Commercially Important Medicinal Plants of Nepal. Ethnobotanical Society of Nepal. Kathmandu.

Rokaya, M.B.; Munzbergova, Z.; Shrestha, M.R. \& Timsina, B. 2012. Distribution patterns of medicinal plants along an elevational gradient in central Himalaya, Nepal. J. Mount. Sci. 9 (2): 201 -213. doi: 10.1007/s11629-012-2144-9

Sher, H. \& Shah, A.H. 2014. Traditional Role of Morels (Morchella spp.) As Food, Medicine and Income in Palas Valley, Pakistan. Biol. Med. 7 (2). doi: 10.4172/09748369.1000E116

Shrestha, P.M. \& Dhillion. 2003. Medicinal Plants diversity and use in the highland of Dolakha district, Nepal. J. Ethnopharm. 86: 81 - 96. 
44 Distribution of prioritized medicinal plants in Nepal

Singh, S.C. \& Nisha, 1976. Some fleshy fungi of Nepal. J. Sci. 6(1): $73-88$.

Stearn, W.T. 1960. Allium and Milula in the Central and Eastern Himalaya. Bull. Brit. Mus. Nat. Hist. (Bot.), 2: 59 - 191.

Thapa, B.B.; Panthi, S.; Rai, R.K.; Shrestha, U.B.; Aryal, A.; Shrestha, S. \& Shrestha, B. 2014. An assessment of Yarsagumba (Ophiocordyceps sinensis) collection in Dhorpatan Hunting Reserve, Nepal. J. Mount. Sci.. 11 (2): 555 - 562.

Tripathi, R.R. 2015. Lauthsallako pat sangkalan tatha prasaran prabidhi. Hamro Kalpabrichhya, 26 (287): 1 - 7. Publ. Department of Forest, Babar Mahal, Kathmandu, Nepal.(In Nepali).

Vetaas, O.R. \& Grytnes, J.A. 2002. Distribution of vascular plant species richness and endemic richness along the Himalayan elevation gradient in Nepal. Global Ecol. and Biogeogr. 11: $291-301$.

Wang, X.L. \& Yao, Y.J. 2011. Host insect species of Ophiocordyceps sinensis: a review. ZooKeys. 127: 43 - 59.

Websites:

http://www.theplantlist.org

http://www.tropicos.org

https://en.wikipedia.org/wiki/APG III system

http://www.iucnredlist.org/search

http://www.efloras.org/flora_page.aspx?flora_id=110 